Kansas State University Libraries

New Prairie Press

\title{
Freirean Dialectics and Dialogue
}

John Holst

University of St.Thomas, jdh91@psu.edu

Follow this and additional works at: https://newprairiepress.org/aerc

Part of the Adult and Continuing Education Administration Commons

(c) (1) (9)

This work is licensed under a Creative Commons Attribution-Noncommercial 4.0 License

\section{Recommended Citation}

Holst, John (2017). "Freirean Dialectics and Dialogue," Adult Education Research Conference. https://newprairiepress.org/aerc/2017/papers/13

This Event is brought to you for free and open access by the Conferences at New Prairie Press. It has been accepted for inclusion in Adult Education Research Conference by an authorized administrator of New Prairie Press. For more information, please contact cads@k-state.edu. 


\title{
Freirean Dialectics and Dialogue
}

\author{
John D. Holst \\ University of St. Thomas
}

\begin{abstract}
In this theoretical inquiry, I explore the importance of dialectics and dialogue in the work of Paulo Freire. I argue that dialectics is key to a social movement-based Freirean pedagogy.
\end{abstract}

Keywords: Freire, dialectics, dialogue, capitalism, social justice

The work of the agronomist-educator...contains a philosophical problem which can neither be ignored nor minimized. As in other cases, it is imperative to reflect philosophically.

Freire (1973) Extension or Communication? (p. 100)

It is no secret nor a profound revelation that we live in an increasingly polarized world. Polarization manifests itself in our politics, culture, and economics. I would argue, however, that polarization is how we experience growing contradictions in the political economy of capitalism on a global scale. Paula Allman (2001) summarized the three major contradictions in capitalism as identified by Marx in his major work Capital: the labor/capital relation, the production/circulation relation, and the forces of production/relations of production relation. She described these contradictions as dialectical contradictions. Allman $(1999,2001)$ drew on Marx for her understanding of dialectics but also on Paulo Freire. What Allman, like many critical adult educators, attempted was to develop a pedagogy to help advance social movements' abilities to understand and confront the causes of polarization rooted in the contradictory nature of capitalism.

Adult educators interested in challenging socio-political economic polarization often find inspiration in and look to Freire's critique of mainstream education and his ideas on alternative methods to educate. When looking to Freire's (2001) critique of what he called "banking education" and to places in his texts where he describes alternative practices, there is often an overemphasis on the educational methods aspect of Freire and a downplaying of the more difficult philosophical currents of his work; Stanley Aronowitz (1993) called this a "fetish of method” (p. 8). Moreover, I believe, the path toward a search for the Freirean method which avoids the philosophical, can lead right back to mainstream practices. What I mean by this is that when one downplays, overlooks, or dismisses the strong philosophical currents in Freire's work, one is left with a search for pedagogical recipes, and the results of these recipes, devoid of Freirean philosophy, can become merely the same reproductive practices people wish to avoid. I have certainly experienced the "Freirean-inspired" teaching method, which consists of the teacher, who confuses preparation and banking, entering the classroom and asking something along the lines of "what would you like to learn about today?”. Or, the Freirean teacher who thinks form can substitute for content and has as his or her main pedagogical methods circular 
seating arrangements and discussion for discussion's sake. Finally, and more subtly, is the cooptation of Freire with a method-only application to contexts he never worked in or intended for his “reinvention” (Freire in Freire \& Macedo, 1987) to take place. Here, I am referring to the focus on basing the content of an educational or training program on themes derived from participants, but void of an ethical consideration. So, for example, one can begin with the idea that "the point of departure of dialogue is the quest for a curriculum" (Freire, 1973, p. 158) and generate themes for a management training session from the managers themselves while overlooking the fact that the objective of the training is to counter the unionization of frontline workers. The educational method is based in the lived realities of manager/participants tasked with maintaining a union-free work environment; yet, from a Freirean (2001) philosophical standpoint, this process becomes “a distortion of the vocation of becoming more human” (p. 44).

In emphasizing Freirean philosophy, I do not mean to imply politically-charged language. In other words, Freirean pedagogy is not circular seating with dogmatic lectures on the ideology of radical revolutions. Rather, by Freirean philosophy, I am referring to, in part, and for the purposes of this paper, the central role of dialectics in his work. I believe a pedagogy centered on an understanding of dialectics can get us beyond the non-dialectical dichotomy between a pedagogy based on an overemphasis on method and a pedagogy based on an overemphasis on politicized rhetoric. Allman's (1999, 2001) work, based in Freirean dialectics and the work of Au (2007, 2012), Gadotti (1996), and Torres (1994, 2014) are very good examples of the approach I will be advocating, and their work is foundational to this paper.

The main purposes of this paper are to provide a straight-forward explanation of dialectics in the work of Paulo Freire; to show how dialectics is foundational to Freire's ideas on dialogue; and to argue for the importance of a dialectical-informed dialogical pedagogy to engage and address the root causes of the growing polarization we are experiencing in our daily lives. Rather than a close textual analysis approach taken by Au (2007) with numerous quotes from Freirean texts, my method of explanation will be a series of propositions; first on dialectics and then on dialogue.

\section{Method of Inquiry}

My propositions are based on a philological investigation of Freire’s major works. In conducting the philological investigation, I draw on both a Gramscian (1971) theoretical framework and the methodological guidelines for philological investigations he outlined in his Prison Notebooks in Notebook 16, Note 2 titled “Questions of Method” (pp. 382-386). Important to this study, then, was to read Freire's $(1973,1978,1985,1993,1998,2001)$ texts on pedagogy, his autobiographical texts (Freire, 1994, 1996) in which he reflects on the historical contexts of both his writing and practice, and his coauthored texts which are both autobiographical and analytical in nature (Freire \& Faundez, 1992; Horton \& Freire, 1990; Freire \& Macedo, 1987; \& Shor \& Freire, 1987). Moreover, given the unchronological nature of the publishing of English translations of his work, it was important to read Freire's work in the order in which they were written in the original, rather than in the order of their English-language publication.

\section{Summary of the Analysis}

The following propositions outline the elements of Freirean dialectics and Freirean dialogue. Apart from two of the propositions, I present them here in abbreviated form to provide an immediate and condensed version of the analysis. In the conclusion, I relate the propositions 
in summative form to the needs of a pedagogy capable of confronting the growing polarization facing us today.

Proposition 1

\section{Freirean Dialectics}

Dialectics is an epistemology and an ontology.

Proposition 2

If the world is ontologically dialectical, to think critically, to have our thinking keep up with or match the nature of reality, is to think dialectically; to capture the dialectical nature of reality.

Thinking dialectically is quite difficult because we generally experience dialectical relationships as dichotomies, and we are generally taught to see things in isolation. For example, we often understand, and are miseducated (Woodson, 2000) to believe, that wealth and poverty are dichotomies; they are opposites, but not dialectical opposites. A "scientific" understanding of poverty can be based on a deep and long-term immersion in poor neighborhoods in order to understand the nature and reality of poverty without any corresponding investigation of the dialectical relationship between poverty and wealth. Miseducation of this type, absent of a dialectical epistemology or ontology, is an example of manipulation (Freire, 2001).

For Freire (1973), in contrast, critical thinking must be based on seeing things interrelatedly. In Education as the Practice of Freedom, Freire introduces methodological steps in educational programing to foster critical consciousness through dialogue. In doing this he draws on fellow Brazilian Álvaro Vieira Pinto, who says that critical consciousness "represents 'things and facts as they exist empirically, in their casual and circumstantial correlation'.... Critical consciousness is integrated with reality” (p. 44). Freire goes on to say that a dialogical method of education is required for establishing situations in which our thinking can match the dynamism of reality. "We wanted to offer the people the means by which...they could assume positions appropriate to the dynamic climate of the transition" (p. 44). He then asks the question "But how could this be done?” (p. 45). He replies to his own question: “The answer seemed to lie: a) in an active dialogical, critical and criticism-stimulating method....Our method, then was to be based on dialogue” (p. 45).

\section{Proposition 3}

To consider something dialectically is to understand that it is the relational aspect of it which defines its nature.

Proposition 4

Dialectical thinking is based on internal relations; dichotomous or dualistic thinking is based on external relations (Allman, 1999).

Recognizing opposites is not difficult; it is a common motif in children's books to provide examples of opposites or pose the challenge of identifying opposites. Generally, however, opposites are considered not dialectically but dualistically, as dichotomies. I will draw on the work of Paula Allman (1999) in explaining the difference between thinking about 
opposites dialectically and dichotomously. To do this, I will use the example of wealth and poverty.

In dichotomous or dualistic thinking, rich and poor are opposites. But they are conceptualized as externally related in that they may come in contact with one another, but the oppositional nature of the two is not considered as a relation between them that defines the essence of either one. Each one is defined by its own internal nature, outside of the relation with the other. Ethnographic research can be based on long-term immersion among the poor in order to understand the internal traits which define them. These traits can be considered as socially created, from a liberal standpoint, or genetically created from conservative or fascist standpoints. The work of Ruby Payne (2013) is based precisely on a dichotomous view of poverty. Her frameworks for understanding poverty are all about explaining the "traits" of the poor in isolation from poverty's dialectical relation with wealth.

The rich can be considered from the same standpoints as the poor from a dichotomous perspective. The rich are rich because of their own internal traits which can be ethnographically studied. Moreover, using a dichotomous philosophical outlook, poverty alleviation can be conducted by extensive research into the traits of the rich and then using this research to create curriculum for teaching the poor how to act like the rich.

A dialectical approach to the reality of poverty and wealth begins with the idea that these opposites are internally related. In other words, neither side can exist or be explained outside the relation with the other; they are two sides of the same pole. To the extent that either end of the pole has internal traits, it is because of the relation between them. The reason there are poor is because there are rich. The reason there is poverty is because there is wealth. The rich and the poor may live on opposite sides of the tracks, but there are rich neighborhoods because there are poor neighborhoods and vice versa. This is the framework within which Freire (2001) discusses the oppressed/oppressor relation. He draws on Hegel's (1977) dialectical analysis of the master/slave relation in which it is impossible to conceive of a slave without considering the existence of a master and vice versa; without one, the other cannot exist. Moreover, the nature of either is dependent on the existence and the relation with the other.

\section{Proposition 5}

Dialectics, or the theory of internal relations, has very revolutionary implications; therefore, dialectics has been called the philosophy of the oppressed.

Proposition 6

Dichotomous thinking does not require major social change. It is then, from a dialectical perspective, the philosophy of the oppressor or a philosophy of charity or liberalism.

Proposition 1

\section{Freirean Dialogue}

True dialogue, as Freire describes it, is the realization of praxis.

Proposition 2

Praxis is the dialectical unity of theory and practice, it is the path to knowledge; knowledge defined as beyond information. 


\section{Proposition 3}

If dialogue is the realization of praxis, knowledge comes from the unity of theory and practice. Without theory, we have only thoughtless action. Without practice, we have merely information.

\section{Conclusion}

I argued in the introduction that we live in an increasingly polarized world. I made the claim that polarization is actually the way in which we experience growing contradictions within the basic relations of capitalism. If I am correct, then why do we need a dialogical pedagogy? Would it not be appropriate to just try and convince as many people as possible that capitalism is in crisis and, therefore, we need some alternative form of production and distribution of the basics of a good life? Given the dire situation of a growing sector of the world's majority across the planet, why spend time "co-investigating” that which we already know?

It is here that we run squarely into Freire's descriptions of radicals and sectarians. For Freire, the goal of the rightwing sectarian is to make sure that tomorrow is just like yesterday and today. In other words, the right sectarian will do anything to ensure that things stay the way they are, even if this means making modest reforms to keep up with the times. The leftwing sectarian also knows yesterday and today, does not like the reality of either, but also knows exactly how tomorrow should differ from yesterday and today. So, unlike the right sectarian, the left sectarian wants to change tomorrow, yet like the right sectarian, the left sectarian has a plan for tomorrow. The pedagogical strategy of both sectarians is banking. One uses monologues to convince people that tomorrow should be just like yesterday and today, while the other uses monologues to convince people that tomorrow should be totally different than yesterday and today. Both have a plan for tomorrow, and have as a goal to win people to their plans.

Again, however, if we already know things are bad and getting worse for the world's majority, is it not appropriate to claim as such and argue for a better tomorrow? For Freire, arguing one's position does not make one a sectarian; in fact, for Freire (1973), radicalization is defined by a growing commitment to one's own beliefs. Nevertheless, a radical, according to Freire (2001), must operate dialogically and based on the dispositions of love for, humility toward, faith in, and hope for the world's majority. Outside of these dispositions, one begins to engage in antidialogical action and becomes increasingly sectarian, increasingly divorced from the world's majority, and increasingly interested in imposing pre-fabricated blueprints for tomorrow.

No one alone, or in a small organization, can know or understand the reality of the world's majority; this has to be an ongoing investigatory pedagogical project of the majority itself in an unending effort to understand and change its own reality and the reality of the minority in the process. A radical can have commitments to ideas and principles and work pedagogically as a part of or with the world's majority, but from a Freirean perspective, because reality is in constant motion and change, knowledge of this reality must also be a process of continuous recreation in order to keep up with an ever-changing reality. A radical, must not, as Marx and Engels (1948) argued over 160 years ago, "set up any sectarian principles....based on ideas...that have been invented, or discovered, by this or that would-be universal reformer” (pp. 22-23), but, rather, must "express... actual relations springing from... a historical movement going on under our very eyes” (p. 23). To express, describe, and understand actual relations 
requires constant investigation, and an investigation involving various people experiencing these actual relations from multiple standpoints.

To understand the actual relations at the heart of capitalism and the cause of polarization, radicals must be in constant contact with those most negatively impacted by these relations in order to understand the relations themselves and their impact on people. It was the Italian radical Antonio Gramsci (1977), who long before Freire, said that "the masses indicated the precise direction of historical development" and that, once one fails to stay in constant contact with the masses, "one becomes estranged from the historical process that is unfolding” (p. 174).

Therefore, dialogical action of a Freirean nature, based on a dialectical understanding of reality and knowledge, is necessary for us to understand the world we live in, while we act in it and on it inspired by a growing commitment to social justice.

\section{References}

Allman, P. (1999). Revolutionary social transformation. Westport, CT: Bergin \& Garvey.

Allman, P. (2001). Critical education against global capitalism. Westport, CT: Bergin \& Garvey.

Aronowitz, S. (1993). Paulo Freire's radical democratic humanism. In P. McLaren \& P. Leonard (Eds.), Paulo Freire: A critical encounter (pp. 8-24). New York: Routledge.

$\mathrm{Au}, \mathrm{W}$. (2007). Epistemology of the oppressed. Journal for Critical Education Policy Studies, 5(2). http://www.jceps.com/?pageID=article\&articleID=100

Au, W. (2012). Critical curriculum studies. New York: Routledge.

Freire, P. (1973). Education for critical consciousness. New York: Continuum.

Freire, P. (1978). Pedagogy in process. London: Writers and Readers Cooperative.

Freire, P. (1985). The politics of education. Westport, CT: Bergin \& Garvey.

Freire, P. (1993). Pedagogy of the city. New York: Continuum.

Freire, P. (1994). Pedagogy of hope. New York: Continuum.

Freire, P. (1996). Letters to Cristina. New York: Routledge.

Freire, P. (1998). Teachers as cultural workers. Boulder, CO: Westview Press.

Freire, P. (2001). Pedagogy of the oppressed. New York: Continuum.

Freire, P., \& Faundez, A. (1992). Learning to question. New York: Continuum.

Freire, P., \& Macedo, D. (1987). Literacy. Westport, CT: Bergin \& Garvey.

Gadotti, M. (1996). Pedagogy of praxis. Albany, NY: SUNY Press.

Gramsci, A. (1971). Selections from the prison notebooks. New York: International Publishers.

Gramsci, A. (1977). Selections from political writings,1910-1920. London: Lawrence \& Wishart. Hegel, G. W. F. (1977). Phenomenology of spirit. Oxford: Oxford University Press.

Horton, M., \& Freire, P. (1990). We make the road by walking. Philadelphia: Temple U. Press. Marx, K. \& Engels, F. (1948). The manifesto of the Communist Party. New York: International. Payne, R. K. (2013). A framework for understanding poverty. Highlands, TX: Aha! Process.

Shor, I., \& Freire, P. (1987). A pedagogy of liberation. New York: Bergin \& Garvey.

Torres, C. A. (1994). Education and the archeology of consciousness: Freire and Hegel. Educational Theory, 44(4), 429-445.

Torres, C. A. (2014). First Freire. New York: Teachers College Press.

Woodson, C. G. (2000). The mis-education of the Negro. Chicago: African American Images. 